\title{
The Sacred Meanings of Yearly "Dreadlock Haircut Ritual" As A Blessing Expectation for Dieng Plateau Society
}

\author{
Atrinawati Atrinawati ${ }^{1}$, Hadiyanto Hadiyanto ${ }^{2}$, Wiwik Sundari $^{3}$ \\ ${ }^{1}$ English Department, Faculty of Humanities, Diponegoro University, Semarang, Indonesia \\ ${ }^{2}$ English Department, Faculty of Humanities, Diponegoro University, Semarang, Indonesia \\ ${ }^{3}$ English Department, Faculty of Humanities, Diponegoro University, Semarang, Indonesia
}

\begin{abstract}
This research paper discusses the Javanese yearly ritual culturally conducted to cut dreadlock hair of Dieng children in the glorified first month of Arabic calendar. The sacral ritual has been long preserved since Dieng native people believe that "dreadlock haircut ritual" is functioned to primarily drive away bad luck, calamity, and life uncertainty for the children when they grow up as well as a blessing expectation for local people life prosperity and happiness. This research is conducted by using descriptive-qualitative research method with profound observation in collecting the related data. The result of the research indicates that yearly "dreadlock haircut ritual", as a matter of fact, has various sacred meanings in terms of psychological-social-cultural perspective, sukerto children, ritual procession, ritual attributes, and salvation ritual.
\end{abstract}

\section{Background of the Research}

Indonesia, based on the data of the latest population census, has more than 270 million inhabitants. Java is the most densely populous island in Indonesia, with the most significant number of Muslim-majority believers. Javanese people have distinguished religious landscapes and varied traditional rituals. A great deal of ethnic Javanese people lives in rural villages and conduct various sacral traditional religious and ritual practices in the countryside as their cultural identity. Most Javanese people identify themselves as Muslims, but the essential roles to the Islamic aspect of their cultural identity vary enormously. This variation is the source of endless controversy for Javanese people themselves. The problem is not merely deciding what counts as Islamic or native Javanese people, but also making cultural variations and living together harmoniously despite different beliefs and rituals. Javanese ritual practices have brought up the underlying concepts of understanding traditional culture, Islam, syncretism or the combination of culture and religion, and ritual meaning.

To understand religious variations and various Javanese rituals, a person has to understand the history of the religions of Javanese people. Long ago, Javanese society was culturally the mixture of Hindu, Buddhist, and indigenous Javanese beliefs. With the coming

Of Islam in Java Island, slowly but surely, Islam finally became society's dominant religion throughout Java. Referring to the history, a lot of Javanese people up to this present time have differed between, firstly, practitioners of a syncretic Javanese tradition and ritual consisting of local folk beliefs, Islam, and Javanese mythology and, secondly, practitioners 
of Islamic teachings, values, and rituals as part of their cultural heritage. Concerning Javanese rituals, "ruwatan" is the best-known and most important of all rituals, which means a sacral ritual to free, release, and salvage someone from any evil spirits (Zoetmulder, 1983:1578). One of the well-known ruwatan rituals is the dreadlock haircut ritual culturally conducted by Dieng plateau society.

The Javanese ritual of dreadlock haircut ruwatan is culturally conducted to cut dreadlock hair of Dieng children in the glorified first month of the Arabic calendar. Based on local people's belief, this dreadlock haircut ritual is carried out to set free children from bad lucks, disaster, and dangerous threats in the future. This kind of ritual is unique since the object of the ruwatan ritual is Dieng children with long dreadlock hair believed to take along with specific weaknesses or sukerto. In Dieng society's perception, if children's specific weakness is not banished by cutting their long dreadlock hair, children's happiness and fortune will not come along in the upcoming days. This ritual has long been preserved from generation to generation by Dieng Muslims Javanese society and other local people to show their cultural awareness of keeping children best when they grow up. The researchers have observed that the dreadlock haircut ritual is not merely a ritual with children as an object but also a communication medium for Dieng local society to pray for a blessing expectation from God for life happiness and prosperity. The researchers have also found the various sacred meanings of dreadlock haircut ritual in terms of psychological-social-cultural perspective, sukerto children, ritual procession, ritual attributes, and salvation ritual.

\section{Method of Research}

\subsection{Research Approach}

The sacred meanings of the yearly "dreadlock haircut ritual" as a blessing expectation for Dieng plateau society are researched using the blended etic and emic research approach. The etic approach of culture is the kind of cultural research approach that emphasizes cultural description and perception based on the outside community. In contrast, the emic approach of culture is a cultural research approach that emphasizes cultural description and perception based on the people's view from the inside local culture community (Kaplan, 2012:29). The etic approach tends to be more objective, whereas the emic approach tends to be subjective (Endraswara, 2012:34). This cultural research also uses qualitative, descriptive research, that is, research conducted using describing, discovering, and explaining any facts, conditions, and phenomena of dreadlock haircut ritual in Dieng society. With this kind of research, the researchers analyze and elaborate the sacred Javanese traditional ritual data, which is closely related to the factual ritual practice and procession in Dieng plateau society and the way of thinking and perception of the local community on dreadlock haircut ritual.

\subsection{Method of Data Collection}

The research on the sacred meanings of the yearly "dreadlock haircut ritual" as a blessing expectation for Dieng plateau society is conducted with several methods. Firstly, this research uses a survey method, that is, by directly visiting the object of the location of Dieng plateau society. By visiting the research object, the researchers conduct and adopt samples of research, such as the traditional ritual practitioners, the elderly figures around the ritual tradition, and the previous dreadlock-haired children in the Dieng plateau, Banjarnegara, Central Java. The researchers share the research samples and ask some critical questions in questioner forms to be answered by some samples of practitioners, elderly figures, and 
previous dreadlock-haired children. The researchers conducted this activity to get factual information about the sacred meanings of the yearly "dreadlock haircut ritual" as a blessing expectation for Dieng plateau society. Secondly, in addition to using questioner forms, the researchers conduct interviews with several respondents of local people around the Dieng plateau by visiting, meeting, and giving questions and answers directly. Some others are conducted online through specific platforms on the internet to gain detailed information about the sacred meanings of the yearly "dreadlock haircut ritual" as a blessing expectation for Dieng plateau society. Thirdly, to complete the accurate data acquired in connection with the dreadlock haircut ritual, the researchers also use the library research method in conducting the research. By using the library research, the researchers attempt to collect the related data of the research object as many as possible through the website on the internet, youtube streaming, books, journals, and any other sources.

\section{The Sacred Meanings of Yearly "Dreadlock Haircut Ritual" as A Blessing Expectation for Dieng Plateau Society}

\subsection{The Sacred Meaning in Psychological-Social-Cultural Perspective}

The dreadlock haircut ritual for Dieng children has been culturally rooted in Dieng plateau society life carried out every early year of the Arabic calendar. The ritual has a sacred meaning in a psychological perspective, that is, a psychological cleansing process from any negative self-image constructions that the children and the practitioners of ritual have in mind. Someone's feeling is determined by the way he or she gives self-image and selfperception. If the self-construction is occupied with something negative, something terrible and anything wrong will befall him or her psychologically. Therefore, they will feel the psychological effects they have constructed themselves. Referring to the emic approach of the cultural phenomena in Dieng, the yearly dreadlock haircut ritual, psychologically, gets rid of someone, children, and Dieng plateau society from restlessness and unpleasantness to peacefulness and happiness. Those who belong to the sacral ritual of dreadlock haircuts will undoubtedly feel uneasy and guilty if they do not get involved with the ritual or carry out the ritual for their dreadlock-haired children. This will lead them to be separated away from the ritual community psychologically.

Based on the etic approach of cultural phenomena analyses, the yearly dreadlock haircut ritual also has a deeper sacred meaning in social perspective, that is, reinforcing and strengthening the social relationship among Dieng plateau society either children, teenagers, adults, older adults, or other visitors who come to follow the ritual. This social phenomenon can be viewed when they gather happily in the ritual procession of dreadlock haircut around the complex of Arjuna temple, Dieng, on the first date of Suro Arabic month. Such a crowded

Ritual indicates social solidarity and togetherness of a strong relationship among the practitioners and visitors of the ritual. In addition to that, this dreadlock haircut ritual causes to emerge a collective awareness to give social charity to the poor people, the orphans, the social facilities, and so on. Undeniably, the ritual event educates Dieng plateau society especially and other visitors generally to have a sense of solidarity. The essential teaching of the dreadlock haircut ruwatan ritual is to get closer to God by sincerely praying for a blessing expectation to Him as the best giver of grace, love, and fortune and to establish a better social relationship by giving charity to other people. This dreadlock haircut ritual reminds Dieng plateau society of sharing happiness and giving a sum of money, delicious foods, proper clothes, or other aids to help the have nots around.

Besides that, referring to the etic approach of cultural phenomena analyses, this dreadlock haircut ritual has a sacred meaning in cultural perspective for Dieng plateau society. This 
ritual is a symbolic cultural identity that differs specifically from other Javanese rituals because it only exists in Dieng. Ritual is a part of a culture that can be seen in society's life. The same as dreadlock haircut ritual, it is a sacral ceremony which has been lasting for hundred years ago and has been performed by a particular group of people in Dieng plateau society, for specific purposes, with specific forms and patterns, in certain times, using certain things, and to acquire certain things from the unseen.

\subsection{The Sacred Meaning of Sukerto Children with Dreadlock Hair}

Dieng plateau society, based on the emic approach of the cultural phenomena in Dieng, has a sacral belief that the dreadlock haircut ritual is carried out for Dieng children to salvage them from sukerto, which means "dirt," "weakness," or "bad luck" of dreadlock-haired children. If it is not ritualized, sukerto will affect children's lives in the future. Sukerto in Javanese belief can be attached within humans as well as physical environments. To drive sukerto away, it needs a ruwatan ritual or an exorcising ritual, such as a dreadlock haircut ritual. Otherwise, sukerto children will face misfortune, calamity, danger in the upcoming days.

Meanwhile, sukerto environment covers plantation, rice field, forest, house yard, and so forth, directly related to humans' lives. All of them are considered something with weakness and misfortune, so their existence becomes potential threats for humans' happiness. In connection with the ritual of sukerto children, dreadlock-haired children are regarded as badluck takers. The researchers analyze such phenomena critically that the negative stereotype and assumption of dreadlock-haired children, perhaps, comes from dirty, smelly hair. As a result, the children will face many health problems, a foul smell of the hair, or a terrible outward appearance. Such badness problems logically lead the children to be avoided by many people around.

\subsection{The Sacred Meaning of Dreadlock Haircut Ritual Procession}

The dreadlock haircut ritual also has a sacred meaning in the ritual procession; the reason behind the dreadlock-haired children has to be ritualized. The elderly figures explain coping with a life problem and the self-adjustment process conducted by dreadlock-haired children. In line with the etic approach of the cultural phenomena in Dieng, the researchers observe that the ritual process begins with the dreadlock-haired children aggregation in the house of the elderly figure of local custom, Dieng, Batur Banjarnegara, Central Java. The age of ritualized children-to-be varies from three to fifteen years old, and they wear Javanese white kabaya clothes and batik underclothes. Anything required by all the

Dreadlock-haired children before the ritual procession have been well-prepared. Subsequently, the children are paraded to go around the kampong before they are sacredly taken a bath with holy prayed water by the elderly figures of the Dieng local community. In the next stage of the ritual procession, all children are taken along in the surrounding yard of the Arjuna temple complex. After Javanese songs and Islamic prayers accompanying the ritual have been sung and said, the procession of the dreadlock haircut ritual is solemnly carried out to be led by the elderly figure of Dieng plateau society.

This time, the dreadlock haircut ritual is a mere sacral ritual, and a part of the cultural tourism agenda conducted every year in Dieng Culture Festivals. The natural phenomena of dreadlock-haired children, based on the local community's belief from time to time, will always emerge around the four surrounding mountains, Sindoro, Sumbing, Prahu, and Rogojembangan. They believe that dreadlock-haired children are supernaturally deposited children given by the spirit son from the south Indian ocean, the bead of Eyang Agung Kolotede for male children, and the bead of Nini Dewi Roro Ronce for female children. 
The sacred meaning behind the dreadlock-haired children having to be ritualized is closely related to the dirty condition of children that will have a significant impact on their health and fortune in the future. It is also sacredly connected with children's cleanliness having to keep as part of life lessons. With the emic approach of the cultural phenomena in Dieng, the sacred meaning of the elderly figures' saying is related to life problems and how to overcome the problems, which means identifying bad things to keep away immediately and good things to do sincerely. The essence of the ritual lies in the life advice for the children, parents, and other visitors about why dreadlock hair can influence a lot on children's life. Hence, life problems appear and how to give solutions and anticipate the upcoming life problems. Meanwhile, the sacred meaning of the self-adjustments process in dreadlock haircut ritual is a time to contemplate and evaluate the parents of children, Dieng native people, and all visitors about the wrongdoings, bad manners, and evil deeds that have been committed all through the life.

\subsection{The Sacred Meaning of Dreadlock Haircut Ritual Attributes}

The dreadlock haircut ritual attributes have a lot of hidden sacred meanings for Dieng plateau society. Essentially, based on the etic approach of the cultural phenomena in Dieng, the dreadlock hair ruwatan ritual is giving charity to other people as a representation of a good deed instructed by God. Humans can be set free from any bad lucks if they are willing to share and give to others and build up a good relationship with God. The dreadlock haircut ritual attributes have sacred symbolic meaning; for example, sesajen, which is collected various servings of foods and fruits, has a sacred meaning as God-given graces to whom humans have to express the deepest gratitude using committing God's instructions and avoiding God's prohibitions in every-day life. Subsequently, Javanese white kabaya worn by the dreadlock-haired children has a deeper meaning as a warning for humans to always remember the day they will die by only wearing white cloth. This white kabaya also has a sacred meaning that living life should first begin with pure acceptance and be based on a clean soul like white kabaya with no stains. Another ritual attribute is large paper-made umbrellas which have a sacred meaning as life protection. It suggests that humans have to be able to protect others with all their might and power maximally. This signifies that all parents should protect their children, teachers should protect their students, leaders should protect their followers, the older people should protect the younger, and so forth.

\subsection{The Sacred Meaning of Dreadlock Haircut as Salvation Ritual}

The dreadlock haircut ritual is an excellent expectation for Dieng plateau society since dreadlock hair is identical with sukerto or bad luck took along naturally that must be fed by having a salvation ritual. Related to the emic and etic approach of the cultural phenomena in Dieng, most of Dieng's local people have practiced Islamic religious values in implementing any good deeds and behaviors. Therefore, this can be analyzed that the Dieng people's motivation to carry out the dreadlock haircut ritual is religious and cultural traditions. Most Dieng plateau society believes that conducting the dreadlock haircut ritual is a salvation ritual of evicting lousy luck away from themselves and being replaced with good luck and serenity. Other local people say that the dreadlock haircut ritual is a salvation ritual to harmonize positive energy and remove negative energy from humans' souls. They believe that the ritual is to anticipate something terrible that may befall humans and family in the future. In living life, humans deal with many bad things that cause positive energy to be tightly blocked. This is due to cursing remarks, harsh words, immoral conduct, evil deeds, repeated sins, and so on. With the dreadlock haircut ritual, negative energy within the children is banished, and 
positive energy retains. Hence, the dreadlock haircut ritual is said to be a salvation ritual affecting children and having an impact on parents, neighbors, and Dieng plateau society in general.

\section{Conclusion}

The Javanese dreadlock haircut ritual is culturally conducted to cut the dreadlock hair of Dieng children in the holy suro, the first month in the Arabic calendar. Concerning the emic and etic approach of the cultural phenomena in Dieng, the sacral ritual has been long preserved because Dieng plateau society believes that the dreadlock haircut ritual is functioned to primarily evict away bad luck, calamity, and life uncertainty for the children, especially when they grow up as well as a blessing expectation for local people life's prosperity and happiness. The yearly dreadlock haircut ritual has various meanings in terms of psychological-social-cultural perspective, sukerto children, ritual procession, ritual attributes, and salvation ritual for the Dieng plateau native community.

\section{References}

1. Bell, Chaterine. Ritual Perspective and Dimension. Oxford University Press, Oxford, 1997.

2. Endraswara, Suwardi. Metodologi Penelitian Kebudayaan. Gadjah Mada University Press, 2012.

3. Geertz, Clifford. The Interpretation of Cultures : Selected Essays. Basic Books Inc Publishers, New York, 1973.

4. Harris, Marvin. Cultural Antrophology. Harper Collins Publishers, New York, 1991.

5. Haviland, William A. Antropologi. (dialihbahasakan Soekadijo), Penerbit Erlangga, Jakarta, 1993.

6. Kaplan, David. et.al. Teori Budaya. Pustaka Pelajar, Yogyakarta. 2012.

7. Kluckhohn, Clyde. A Mirror for Man, McGraw-Hill Publishing, Harvard, USA, 1949.

8. Salamone, Frank A. Encyclopedia of Religious Rites, Rituals, and Festivals. Routledge, New York, London, 2004.

9. Soelaeman, M. Munandar. Ilmu Budaya Dasar: Suatu Pengantar. Refika, Bandung, 2001.

10. Sutrisno, Mudji. et.al. Teori-Teori Kebudayaan. Kanisius, Yogyakarta, 2005.

11. Thohir, Mudjahirin. Teori-Teori Kebudayaan. Pascasarjana Universitas Diponegoro Semarang Press, 2005.

12. Zetmulder. Kalangwan. Jakarta: Penerbit Djambatan. 1982. 